\title{
PHYSICO-CHEMICAL CHARACTERIZATION OF MENTHA PULEGIUM L. ESSENTIAL OILS FROM THE TIARET REGION
}

\author{
Djamila Mezouar ${ }^{1,2, *}$, Ali Bensaad ${ }^{1}$, Abedelsalem Benzzarouk ${ }^{1}$, Rahma Affane ${ }^{1}$, \\ Houria Rebhi ${ }^{1}$, Torkia Berrezoug ${ }^{1}$ \\ ${ }^{1 *}$ Department of Natural and Life Sciences, Faculty of Natural and Life Sciences, \\ University of Tiaret 14000, Algeria; \\ ${ }^{2 *}$ Laboratory of Physiology, Pathophysiology and Biochemistry of Nutrition, Department of Biology, Faculty of \\ Natural and Life Sciences, Earth and Universe Sciences, Abu Bekr Belkaid University of Tlemcen 13000, Algeria;
}

*Corresponding Author Mezouar Djamila: e-mail: djamila.mezouar@univ-tiaret.dz;

Received August 2021; Accepted September 2021; Published October 2021;

DOI: $\underline{\text { https://doi.org/10.31407/ijees11.435 }}$

\begin{abstract}
Objectives. The objective of our study aimed to extract and determine some physicochemical characteristics of Mentha pulegium L. essential oil. Materials and methods. The samples of Mentha pulegium L. were collected in May 2021 in the region of Tiaret and identified by a botanist at the Faculty of Natural and Life Sciences, University of Tiaret. The leaves of Mentha pulegium L. were washed, sorted and dried in the open air at room temperature (about $23-27^{\circ} \mathrm{C}$ ) for two weeks, then they were crushed in a mortar. After that, the leaves obtained were stored in sealed glass containers protected from light and moisture. The extraction of Mentha pulegium L. essential was realized by hydrodistillation technique. Results. Our results showed that the extraction yield is equal to $0.18 \%$. The study of the physicochemical parameters indicated that the $\mathrm{pH}$ is equal to 5.22. Regarding the acid number, we noted a value equal to 0.28 . Whereas, the refractive index was equal to 1.332 . Conclusion. These parameters are used to determine the quality of Mentha pulegium L. essential oil. According to our results, we can say that the essential oil in our study is of intermediate physicochemical quality.
\end{abstract}

Key words: Mentha pulegium L., hydrodistillation, essential oils, physicochemical characteristics, Tiaret. 